\title{
Association between Internet Gaming Disorder or Pathological Video-Game Use and Comorbid Psychopathology: A Comprehensive Review
}

\author{
Vega González-Bueso ${ }^{1, \dagger}{ }^{\dagger}$ Juan José Santamaría ${ }^{1, *, \dagger}$, Daniel Fernández ${ }^{2,3}{ }^{\mathbb{D}}$, Laura Merino ${ }^{1}$, \\ Elena Montero ${ }^{1}$ and Joan Ribas ${ }^{1}$ \\ 1 Atención e Investigación en Socioadicciones (AIS), Mental Health and Addictions Network, \\ Generalitat de Catalunya (XHUB), C/Forn-7-9 Local, 08014 Barcelona, Spain; \\ vgonzalez@ais-info.org (V.G.-B.); lmerino@ais-info.org (L.M.); \\ emontero@ais-info.org (E.M.); 38039jrs@comb.cat (J.R.) \\ 2 Research and Development Unit, Parc Sanitari Sant Joan de Déu, Fundació Sant Joan de Déu, CIBERSAM, \\ Dr. Antoni Pujadas, 42, Sant Boi de Llobregat, 08830 Barcelona, Spain; df.martinez@pssjd.org \\ 3 School of Mathematics and Statistics, Victoria University of Wellington, Wellington 6140, New Zealand \\ * Correspondence: jsantamaria@ais-info.org; Tel.: +34-93-301-3024 \\ + These authors contributed equally to this work.
}

Received: 27 February 2018; Accepted: 31 March 2018; Published: 3 April 2018

\begin{abstract}
The addictive use of video games is recognized as a problem with clinical relevance and is included in international diagnostic manuals and classifications of diseases. The association between "Internet addiction" and mental health has been well documented across a range of investigations. However, a major drawback of these studies is that no controls have been placed on the type of Internet use investigated. The aim of this study is to review systematically the current literature in order to explore the association between Internet Gaming Disorder (IGD) and psychopathology. An electronic literature search was conducted using PubMed, PsychINFO, ScienceDirect, Web of Science and Google Scholar (r.n. CRD42018082398). The effect sizes for the observed correlations were identified or computed. Twenty-four articles met the eligibility criteria. The studies included comprised 21 cross-sectional and three prospective designs. Most of the research was conducted in Europe. The significant correlations reported comprised: $92 \%$ between IGD and anxiety, $89 \%$ with depression, $85 \%$ with symptoms of attention deficit hyperactivity disorder (ADHD), and $75 \%$ with social phobia/anxiety and obsessive-compulsive symptoms. Most of the studies reported higher rates of IGD in males. The lack of longitudinal studies and the contradictory results obtained prevent detection of the directionality of the associations and, furthermore, show the complex relationship between both phenomena.
\end{abstract}

Keywords: pathological video-game use; Internet Gaming Disorder; comorbid psychopathology; review

\section{Introduction}

The problematic use of video games is recognized by mental health professionals as an addictive behavior with clinical relevance. This is due to the negative consequences it may have for affected people in several functional areas such as relationship conflicts, sleep problems or occupational functioning [1,2]. However, in the current literature, the terms "Internet addiction" (IA) and "pathological Internet use" (PIU) have commonly been used to refer to all sorts of activities including, but not limited to, the use of video games. All these activities are derived from the excessive use of devices connected to the Internet (i.e., computers, smartphones and other devices to play on and navigate). This classification has frequently been criticized as being too broad and not distinguishing 
between problematic activities and the medium itself on which they take place [3,4], despite the fact that persons engaged in these activities have different sociodemographic characteristics and motivations [5]. For example, the Internet preference activities for males are those related to entertainment and leisure, whereas women tend to choose activities related to interpersonal communication and educational assistance; additionally, these differences may be mediated by age [6]

The non-inclusion of IA as a diagnosis, and the inclusion of "Internet Video-Game Disorder" (Internet Gaming Disorder, IGD) in Section III of the diagnostic manual DSM-5 [7] as a condition that requires further study, seems to support considering both disorders as different problems. Likewise, the most recent inclusion of Gaming Disorder in the beta version of the ICD-11 (International Classification of Diseases) of the World Health Organization [8] seems to confirm this trend. In this document, the problem is defined as "a pattern of persistent or recurrent gaming behavior ('digital gaming' or 'video-gaming'), which may be online (i.e., over the Internet) or offline, manifested by: (1) impaired control over gaming (e.g., onset, frequency, intensity, duration, termination, context); (2) increasing priority given to gaming to the extent that gaming takes precedence over other life interests and daily activities; and (3) continuation or escalation of gaming despite the occurrence of negative consequences. The behavior pattern is of sufficient severity to result in significant impairment in personal, family, social, educational, occupational or other important areas of functioning. The pattern of gaming behavior may be either continuous or, on the other hand, episodic and recurrent. The gaming behavior and other features are normally evident over a period of at least 12 months for a diagnosis to be assigned, although the required duration may be shortened if all diagnostic requirements are met and symptoms are severe".

The psychopathology associated with addictive behaviors, with or without substance, can result from a problem or, alternatively, lead to further issues $[9,10]$. If the association between two disorders is higher than expected by chance, it is likely that there are mechanisms contributing to that association. Four general models of increased comorbidity have been described [11-13]: common factor models, secondary substance-use disorder models, secondary psychiatric disorder models, and bidirectional models. In the first instance, both disorders share risk factors and the higher comorbidity is the result. In the second case, the addictive disorder contributes to other psychiatric disorders. In the third condition, the psychiatric disorder precipitates the addictive behavior. Finally, either disorder can increase vulnerability to the other disorder; in such cases the higher comorbidity reported may be due to inappropriate sampling, assessment, study design or other biases in the published studies.

In the case of behavioral addictions, the temporal linearity of that relationship remains unclear. Associations between IA or PIU and various psychiatric symptoms have been reported in the literature. Specifically, they have been related to depression, attention deficit hyperactivity disorder (ADHD), anxiety, obsessive-compulsive symptoms, and hostility or aggression [14]. Depression seems to be the most common comorbidity in all age groups (adolescents, adults and the general population). However, the designs used to explore these relationships are not sufficiently comprehensive or complex to confirm the hypothesis for the above models. It is possible that a specific psychiatric problem might have an influence on developing an IA, or that a person with an IA diagnosis, due to various negative consequences, will later develop a comorbid psychiatric disorder. It is also possible that both problems share biological, sociodemographic or psychological underlying mechanisms that make people vulnerable to both pathologies; these may thus become evident at the same time [15]. A major drawback of these studies is that, in most, the type of Internet use is not controlled or, alternatively, the results are not separated by use. In many studies, playing video games is the most common activity among people with IA [16-19]; still, the results have been analyzed without taking this aspect into account.

Therefore, some interesting questions remain. One is whether IGD has similar comorbidities to IA or, rather, the comorbidities are different. In the latter case, one may wonder if other Internet-based issues are affecting in some way the results of studies focused on IA in general. An additional question pertains to the directionality of both conditions (IGD and psychopathology). 
The aim of this study is to review systematically the current literature to elicit epidemiological evidence supporting or refuting the association between Internet gaming addiction and psychopathology. An additional objective is to explore the relationship between these conditions. Such results can furnish clinicians with updated information and provide a direction for future investigative endeavors.

\section{Materials and Methods}

This systematic review was conducted in accordance with the Preferred Reporting Items for Systematic Reviews and Meta-Analyses-P 2015 statement for systematic review and meta-analysis protocols [20]. The databases reviewed between October and December 2017 were PubMed, PsychINFO, ScienceDirect, Web of Science, and Google Scholar, using the following search terms and logic: "(Internet OR online) gaming addiction AND (psychopathology OR comorbidity)". Without considering the results in Google Scholar, these database search parameters yielded a total of 688 results, including the following results in each database: PubMed (54 results), PsychINFO (354 results), and ScienceDirect (280 results). Due to the large number of results provided by Google Scholar (more than 17,500 results), we reviewed only the first 30 pages of results. Additional articles were identified through searching the citations in the literature selected.

The studies were systematically and independently reviewed by the authors (Vega González-Bueso and Juan José Santamaría); paying attention to the study type, study population, methodology, outcome measures, effect sizes and interpretation of results. In cases of discrepancies, these were resolved through consensus or referral to a third reviewer (Laura Merino). The inclusion criteria were: (i) the inclusion of empirically collected data; (ii) IGD assessed by standardized questionnaires or other proposed criteria based on international disease classifications; (iii) psychiatric comorbidity assessed by standardized questionnaires; (iv) availability of the full text; (v) published after the year 2010 (this allowed us to review the most recent research in a field where the subject of addiction evolves rapidly); (vi) written in English or in Spanish (the two languages known by the authors); and (vii) article published in a peer-reviewed journal.

Studies were also included if the object of research was IA, only if it was specified that the Internet was used to play video games, and/or the results were separated according to Internet use and whether video games were one of those activities.

The exclusion criteria were: (i) articles containing only anecdotal evidence on psychopathology associated with IGD; (ii) authors not providing a specific definition or criteria for IGD; (iii) case reports and case series; (iv) studies only reporting results on phenomenons such as motivation to play video games, decision-making, stress, lifestyle, impulsivity and sexual attitude, without reporting other psychiatric comorbidity.

A review protocol exists at the PROSPERO International prospective register of systematic reviews [21] registration number CRD42018082398.

In order to facilitate the comparisons with pathological Internet use, the reviewing method applied by Carli et al. in 2013 [14] was followed: the effect sizes of the associations between IGD and psychopathology were identified by the reviewed publications or calculated using the data provided by the authors, when available. In order to compare the different associations, the effect sizes $\mathrm{d}$ and $\mathrm{R}^{2}$ were stated as small, moderate, or large, according to Cohen [22]; OR were converted into these groups according to Chinn [23]. The effect sizes were interpreted accordingly: small $(\mathrm{d}=0.2$, $\left.\mathrm{R}^{2}=0.01, \mathrm{OR}=1.45\right)$, moderate $\left(\mathrm{d}=0.5, \mathrm{R}^{2}=0.06, \mathrm{OR}=2.50\right)$, and large $\left(\mathrm{d}=0.8, \mathrm{R}^{2}=0.14, \mathrm{OR}=4.25\right)$. Full association was considered when a correlation was found for both genders after multivariate analyses. If a correlation was identified for only one gender, it was classified as a partial association. The geographical distribution of studies was also mapped (Figure 1). 


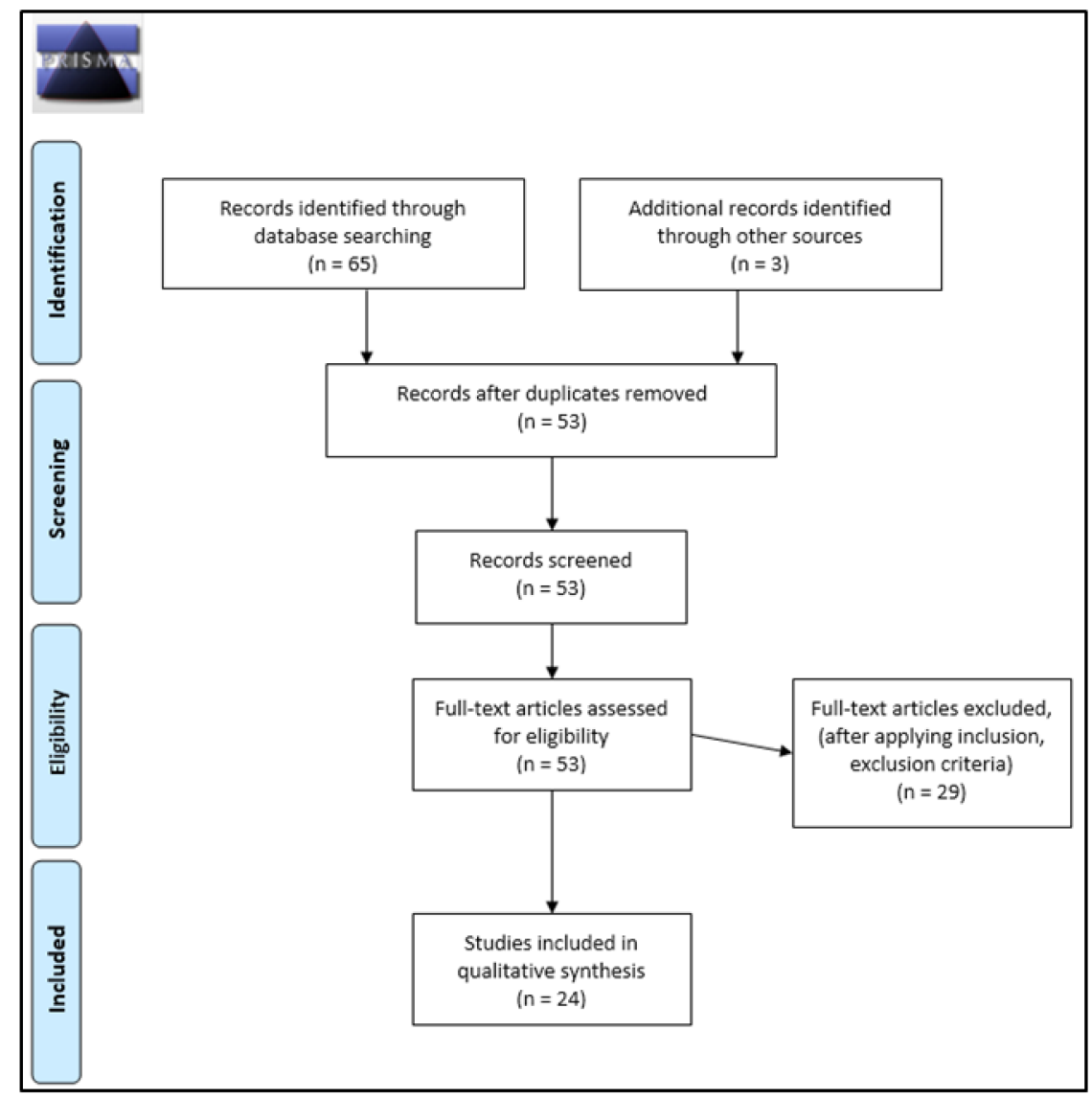

Figure 1. PRISMA 2009 protocols flow diagram.

\section{Results}

After deleting duplicate studies, a total of 68 articles were screened and identified through the present systematic search. After applying inclusion and exclusion criteria, a total of 24 studies were selected and included. Table 1 shows a summary of the main characteristics of the studies examining the relationship between IGD and comorbid psychopathology, including effect sizes. 
Table 1. Studies examining the relationship between Internet Gaming Disorder (IGD) and comorbid psychopathology, including effect sizes.

\begin{tabular}{|c|c|c|c|c|c|c|c|c|c|c|c|}
\hline Source & Study Type & $N$ & $\begin{array}{l}\text { Population } \\
\text { Age }^{\mathrm{a}}\end{array}$ & Sex & Country & IGD Measures & $\begin{array}{c}\text { Psychopathology } \\
\text { Measures }\end{array}$ & $\begin{array}{c}\text { Psychopathology } \\
\text { Outcome }\end{array}$ & Association & Effect Size & $95 \% \mathrm{CI}$ of $\mathrm{c}$ \\
\hline \multirow[t]{2}{*}{$\begin{array}{l}\text { Baer et al., } \\
2011[24]\end{array}$} & cross-sectional & 102 & $\begin{array}{c}\text { adolescents } \\
13.7 \pm 1.9\end{array}$ & $\mathrm{M} / \mathrm{F}$ & Canada & $\begin{array}{l}\text { Computer/Gaming-station } \\
\text { Addiction Scale (CGAS) }\end{array}$ & $\begin{array}{c}\text { Strengths and Difficulties } \\
\text { Questionnaire }\end{array}$ & Emotional problems & full & $R^{2}=0.29$ & - \\
\hline & & & & & & & & Hyperactivity & full & $\mathrm{R}^{2}=0.18$ & - \\
\hline \multirow[t]{3}{*}{$\begin{array}{l}\text { Cole \& Hooley, } \\
2013 \text { [25] }\end{array}$} & cross-sectional & 163 & $\begin{array}{c}\text { general } \\
\text { population } \\
27.3 \pm 9.1\end{array}$ & $\mathrm{M} / \mathrm{F}$ & USA & $\begin{array}{c}\text { Generalized Problematic } \\
\text { Internet Use Scale } \\
\text { (GPIUS) }\end{array}$ & $\begin{array}{l}\text { State-Trait Anxiety } \\
\text { Inventory (STAI) }\end{array}$ & Anxiety state & full & $\mathrm{d}=0.26$ & $-0.05-0.57$ \\
\hline & & & & & & & & Anxiety trait & full & $\mathrm{d}=1.07$ & $0.74-1.40$ \\
\hline & & & & & & & Social Phobia Scale & Social phobia & full & $\mathrm{d}=1.17$ & $0.83-1.50$ \\
\hline \multirow[t]{9}{*}{$\begin{array}{l}\text { Jiménez-Murcia } \\
\text { et al., } 2014 \text { [26] }\end{array}$} & cross-sectional & 193 & $\begin{array}{c}\text { adults with GD } \\
42.4 \pm 13.4\end{array}$ & $\mathrm{M} / \mathrm{F}$ & Spain & $\begin{array}{c}\text { Video-game Dependency } \\
\text { Test (VDT) }\end{array}$ & $\begin{array}{c}\text { Symptom Checklist } \\
\text { 90-revision }\end{array}$ & Somatization & full & $\mathrm{d}=0.57$ & $0.16-0.983$ \\
\hline & & & & & & & & Obsessive-Compulsive & full & $\mathrm{d}=0.84$ & $0.424-1.257$ \\
\hline & & & & & & & & $\begin{array}{l}\text { Interpersonal } \\
\text { Sensitivity }\end{array}$ & full & $\mathrm{d}=0.76$ & $0.341-1.169$ \\
\hline & & & & & & & & Depression & full & $\mathrm{d}=0.58$ & $0.17-0.991$ \\
\hline & & & & & & & & Anxiety & full & $\mathrm{d}=0.64$ & $0.216-1.064$ \\
\hline & & & & & & & & Hostility & full & $\mathrm{d}=0.68$ & $0.255-1.106$ \\
\hline & & & & & & & & Phobic-Anxiety & full & $\mathrm{d}=0.55$ & $0.127-0.973$ \\
\hline & & & & & & & & Paranoid Ideation & full & $\mathrm{d}=0.83$ & $0.402-1.259$ \\
\hline & & & & & & & & Psychoticism & full & $\mathrm{d}=0.56$ & $0.137-0.983$ \\
\hline \multirow[t]{9}{*}{$\begin{array}{l}\text { Kim et al., } \\
2016 \text { [27] }\end{array}$} & cross-sectional & 3041 & adults $20-49$ & $\mathrm{M} / \mathrm{F}$ & South Korea & $\begin{array}{l}\text { IGD diagnostic criteria } \\
\text { in DSM-5 }\end{array}$ & $\begin{array}{l}\text { Brief Symptom } \\
\text { Inventory (BSI) }\end{array}$ & Somatization & full & $\mathrm{d}=1.59$ & $1.481-1.703$ \\
\hline & & & & & & & & Obsessive-Compulsive & full & $\mathrm{d}=1.67$ & $1.557-1.78$ \\
\hline & & & & & & & & $\begin{array}{l}\text { Interpersonal } \\
\text { Sensitivity }\end{array}$ & full & $\mathrm{d}=1.61$ & $1.499-1.721$ \\
\hline & & & & & & & & Depression & full & $\mathrm{d}=1.75$ & $1.642-1.867$ \\
\hline & & & & & & & & Anxiety & full & $\mathrm{d}=1.75$ & $1.642-1.866$ \\
\hline & & & & & & & & Hostility & full & $\mathrm{d}=1.72$ & $1.61-1.834$ \\
\hline & & & & & & & & Phobic-Anxiety & full & $\mathrm{d}=1.82$ & $1.705-1.928$ \\
\hline & & & & & & & & Paranoid Ideation & full & $\mathrm{d}=1.74$ & $1.623-1.847$ \\
\hline & & & & & & & & Psychoticism & full & $\mathrm{d}=1.76$ & $1.646-1.87$ \\
\hline $\begin{array}{l}\text { King et al., } \\
2013 \text { [28] }\end{array}$ & cross-sectional & 1287 & $\begin{array}{l}\text { adolescents } \\
\quad 12-18\end{array}$ & $\mathrm{M} / \mathrm{F}$ & Australia & $\begin{array}{l}\text { Pathological Technology } \\
\text { Use (PTU) }\end{array}$ & $\begin{array}{c}\text { Revised Children's } \\
\text { Anxiety and } \\
\text { Depression Scale }\end{array}$ & Depression & none & - & \\
\hline
\end{tabular}


Table 1. Cont

\begin{tabular}{|c|c|c|c|c|c|c|c|c|c|c|c|}
\hline Source & Study Type & $N$ & $\begin{array}{l}\text { Population } \\
\text { Age }^{\text {a }}\end{array}$ & Sex & Country & IGD Measures & $\begin{array}{c}\text { Psychopathology } \\
\text { Measures }\end{array}$ & $\begin{array}{c}\text { Psychopathology } \\
\text { Outcome }\end{array}$ & Association & Effect Size & $95 \%$ CI of $d$ \\
\hline & & & & & & & & $\begin{array}{l}\text { Obsessive-Compulsive } \\
\text { Disorder (OCD) }\end{array}$ & none & - & \\
\hline & & & & & & & & Anxiety & none & - & \\
\hline \multirow[t]{2}{*}{$\begin{array}{c}\text { King \& } \\
\text { Delfabbro, } \\
2016 \text { [29] }\end{array}$} & cross-sectional & 824 & $\begin{array}{l}\text { adolescents } \\
14.1 \pm 1.5\end{array}$ & $\mathrm{M} / \mathrm{F}$ & Australia & $\begin{array}{l}\text { IGD Diagnostic criteria } \\
\text { in DSM-5 }\end{array}$ & $\begin{array}{l}\text { Depression Anxiety Stress } \\
\text { Scales, 21-item version }\end{array}$ & Depression & full * & $d=0.62$ & $0.087-1.155$ \\
\hline & & & & & & & & Anxiety & full * & $\mathrm{d}=0.50$ & $-0.035-1.025$ \\
\hline $\begin{array}{l}\text { Laconi et al., } \\
2017[30]\end{array}$ & cross-sectional & 418 & $\begin{array}{c}\text { adults } \\
21.9 \pm 3\end{array}$ & $\mathrm{M} / \mathrm{F}$ & France & $\begin{array}{l}\text { Internet Gaming Disorder } \\
\text { Test-10 (IGDT-10) }\end{array}$ & $\begin{array}{l}\text { Center for Epidemiologic } \\
\text { Studies, Depression } \\
\text { Scale-10 } \\
\end{array}$ & Depression & full & $\mathrm{d}=2.687$ & $1.969-3.405$ \\
\hline \multirow[t]{2}{*}{$\begin{array}{l}\text { Männikkö } \\
\text { et al., } 2015 \text { [31] }\end{array}$} & cross-sectional & 293 & $\begin{array}{c}\text { general } \\
\text { population } \\
18.7 \pm 3.4\end{array}$ & $\mathrm{M} / \mathrm{F}$ & Finland & $\begin{array}{l}\text { Gaming Addiction } \\
\text { Scale (GAS) }\end{array}$ & $\begin{array}{l}\text { School Health } \\
\text { Promotion (SHP) }\end{array}$ & Depression & full & $R^{2}=0.17$ & - \\
\hline & & & & & & & & Anxiety & full & $R^{2}=0.11$ & - \\
\hline \multirow[t]{2}{*}{$\begin{array}{l}\text { Mentzoni, } \\
\text { et al., } 2011 \text { [32] }\end{array}$} & cross-sectional & 816 & $\begin{array}{c}\text { general } \\
\text { population } \\
15-40 \\
\end{array}$ & $\mathrm{M} / \mathrm{F}$ & Norway & $\begin{array}{l}\text { Gaming Addiction Scale } \\
\text { for Adolescents (GASA) }\end{array}$ & $\begin{array}{l}\text { Hospital Anxiety and } \\
\text { Depression Scale (HADS) }\end{array}$ & Depression & full & $\mathrm{n} / \mathrm{a}$ & - \\
\hline & & & & & & & & Anxiety & full & $\mathrm{n} / \mathrm{a}$ & - \\
\hline \multirow[t]{2}{*}{$\begin{array}{l}\text { Müller et al., } \\
2015 \text { [33] }\end{array}$} & cross-sectional & 12,938 & $\begin{array}{c}\text { adolescents } \\
15.8 \pm 0.7\end{array}$ & $\mathrm{M} / \mathrm{F}$ & Germany & $\begin{array}{l}\text { Assessment of Internet } \\
\text { and Computer Game } \\
\text { Addiction (AICGA) }\end{array}$ & Youth Self-Report & Anxious-Depression & full & $\mathrm{d}=0.34$ & $0.183-0.496$ \\
\hline & & & & & & & & Withdrawn-Depression & full & $\mathrm{d}=0.35$ & $0.347-0.507$ \\
\hline \multirow[t]{2}{*}{$\begin{array}{l}\text { Na et al., } \\
2017 \text { [34] }\end{array}$} & cross-sectional & 1819 & adults $20-49$ & $\mathrm{M} / \mathrm{F}$ & South Korea & $\begin{array}{l}\text { IGD diagnostic criteria } \\
\text { in DSM-5 }\end{array}$ & $\begin{array}{c}\text { Symptom Checklist } \\
\text { 90-revision }\end{array}$ & Depression & full & $\mathrm{n} / \mathrm{a}$ & - \\
\hline & & & & & & & & Anxiety & full & $\mathrm{n} / \mathrm{a}$ & - \\
\hline \multirow[t]{6}{*}{$\begin{array}{l}\text { Starcevic et al., } \\
\quad 2011 \text { [35] }\end{array}$} & cross-sectional & 1945 & $\begin{array}{l}\text { general } \\
\text { population } \\
\text { over 14 }\end{array}$ & $\mathrm{M} / \mathrm{F}$ & Australia & $\begin{array}{c}\text { Video-Game Use } \\
\text { Questionnaire (VGUQ) }\end{array}$ & Symptom Checklist 90 & Somatization & partial> & $\mathrm{d}=1.02$ & $0.854-1.187$ \\
\hline & & & & & & & & Obsessive-Compulsive & partial & $\mathrm{d}=1.365$ & $1.196-1.534$ \\
\hline & & & & & & & & $\begin{array}{l}\text { Interpersonal } \\
\text { Sensitivity }\end{array}$ & partial & $\mathrm{d}=1.228$ & $1.059-1.396$ \\
\hline & & & & & & & & Depression & partial & $\mathrm{d}=1.264$ & $1.096-1.433$ \\
\hline & & & & & & & & Anxiety & partial> & $\mathrm{d}=1.149$ & $0.981-1.317$ \\
\hline & & & & & & & & Hostility & partial> & $\mathrm{d}=1.276$ & $1.108-1.445$ \\
\hline
\end{tabular}


Table 1. Cont

\begin{tabular}{|c|c|c|c|c|c|c|c|c|c|c|c|}
\hline Source & Study Type & $N$ & $\begin{array}{l}\text { Population } \\
\text { Age }^{a}\end{array}$ & Sex & Country & IGD Measures & $\begin{array}{c}\text { Psychopathology } \\
\text { Measures }\end{array}$ & $\begin{array}{c}\text { Psychopathology } \\
\text { Outcome }\end{array}$ & Association & Effect Size & $95 \%$ CI of \\
\hline & & & & & & & & Phobic-Anxiety & partial> & $\mathrm{d}=1.131$ & $0.964-1.299$ \\
\hline & & & & & & & & Paranoid Ideation & partial> & $d=1.203$ & $1.035-1.371$ \\
\hline & & & & & & & & Psychoticism & partial> & $\mathrm{d}=1.368$ & $1.199-1.537$ \\
\hline $\begin{array}{l}\text { Stetina et al., } \\
2011 \text { [36] }\end{array}$ & cross-sectional & 468 & $\begin{array}{l}\text { general } \\
\text { population } \\
11-67\end{array}$ & $\mathrm{M} / \mathrm{F}$ & Austria & $\begin{array}{l}\text { Problematic Internet use } \\
\text { scale (ISS-20) }\end{array}$ & $\begin{array}{l}\text { Questionnaire for } \\
\text { depression diagnostics } \\
\text { (FDD for DSM-IV) }\end{array}$ & Depression & none & - & - \\
\hline \multirow[t]{2}{*}{$\begin{array}{l}\text { Strittmatter } \\
\text { et al., } 2015 \text { [37] }\end{array}$} & cross-sectional & 9758 & $\begin{array}{l}\text { adolescents } \\
15.0 \pm 1.3\end{array}$ & $\mathrm{M} / \mathrm{F}$ & Germany & $\begin{array}{c}\text { Young Diagnostic } \\
\text { Questionnaire (YDQ) }\end{array}$ & $\begin{array}{l}\text { Beck Depression } \\
\text { Inventory II }\end{array}$ & Depression & full & $\mathrm{d}=0.58$ & $0.449-0.702$ \\
\hline & & & & & & & $\begin{array}{l}\text { Strengths and Difficulties } \\
\text { Questionnaire (SDQ) }\end{array}$ & Hyperactivity & full & $\mathrm{d}=0.53$ & $0.399-0.652$ \\
\hline \multirow[t]{4}{*}{$\begin{array}{l}\text { Vadlin et al., } \\
2016[38]\end{array}$} & cross-sectional & $\begin{array}{c}1 \\
(1868) \\
N 2 \\
(242) \\
\end{array}$ & $\begin{array}{l}\text { adolescents } \\
12-18\end{array}$ & $\mathrm{M} / \mathrm{F}$ & Sweden & $\begin{array}{l}\text { Gaming Addiction } \\
\text { Identification (GAIT) }\end{array}$ & $\begin{array}{l}\text { Depression Self-Rating } \\
\text { Scale (DSRS-A) }\end{array}$ & Depression & full & $\begin{array}{l}\text { OR 2.47 } \\
(1.44-4.25)\end{array}$ & - \\
\hline & & & & & & & $\begin{array}{l}\text { Spence Children's Anxiety } \\
\text { Scale (SCAS) }\end{array}$ & Anxiety & full & $\begin{array}{c}\text { OR 2.06 } \\
(1.27-3.33)\end{array}$ & - \\
\hline & & & & & & & $\begin{array}{l}\text { Adult ADHD Self-Report } \\
\text { Scale (ASRS-A) }\end{array}$ & $\begin{array}{c}\text { Attention Deficit } \\
\text { Hyperactivity } \\
\text { Disorder (ADHD) }\end{array}$ & full & $\begin{array}{c}\text { OR } 2.43 \\
(1.44-4.11)\end{array}$ & - \\
\hline & & & & & & & $\begin{array}{c}\text { Psychotic-like } \\
\text { experiences (PLEs) }\end{array}$ & Psychoticism & none & - & - \\
\hline \multirow[t]{2}{*}{$\begin{array}{l}\text { Wang et al., } \\
2018 \text { [39] }\end{array}$} & cross-sectional & 7200 & $\begin{array}{l}\text { general } \\
\text { population } \\
14-39\end{array}$ & $\mathrm{M} / \mathrm{F}$ & South Korea & $\begin{array}{l}\text { IGD diagnostic criteria } \\
\text { in DSM-5 }\end{array}$ & $\begin{array}{c}\text { Patient Health } \\
\text { Questionnaire9 (PHQ9) }\end{array}$ & Depression & full & $\mathrm{n} / \mathrm{a}$ & - \\
\hline & & & & & & & $\begin{array}{c}\text { Generalized Anxiety } \\
\text { Disorder Scale (GAD-7) }\end{array}$ & Anxiety & $\mathrm{n} / \mathrm{a}$ & - & - \\
\hline \multirow[t]{2}{*}{$\begin{array}{l}\text { Wartberg et al., } \\
2017 \text { [40] }\end{array}$} & cross-sectional & 1095 & $\begin{array}{l}\text { adolescents } \\
13.0 \pm 0.82\end{array}$ & $\mathrm{M} / \mathrm{F}$ & Germany & $\begin{array}{l}\text { Internet Gaming Disorder } \\
\text { Scale (IGDS) }\end{array}$ & $\begin{array}{l}\text { Reynolds Adolescent } \\
\text { Adjustment Screening } \\
\text { Inventory }\end{array}$ & $\begin{array}{l}\text { Depression and } \\
\text { anxiety }\end{array}$ & full & $\begin{array}{c}\text { OR } 1.09 \\
(1.02-1.17)\end{array}$ & - \\
\hline & & & & & & & & Hyperactivity & full & $\begin{array}{c}\text { OR 1.27 } \\
(1.16-1.39)\end{array}$ & - \\
\hline $\begin{array}{l}\text { Wei et al., } \\
2012 \text { [41] }\end{array}$ & cross-sectional & 722 & $\begin{array}{c}\text { general } \\
\text { population } \\
21.8 \pm 4.9\end{array}$ & $\mathrm{M} / \mathrm{F}$ & Taiwan & $\begin{array}{l}\text { Chen's Internet Addiction } \\
\text { Scale (CIAS) }\end{array}$ & $\begin{array}{l}\text { Depression and Somatic } \\
\text { Symptoms Scale (DSSS) }\end{array}$ & Depression & full & $R^{2}=0.298$ & - \\
\hline
\end{tabular}


Table 1. Cont.

\begin{tabular}{|c|c|c|c|c|c|c|c|c|c|c|c|}
\hline Source & Study Type & $N$ & $\begin{array}{c}\text { Population } \\
\text { Age }^{\mathrm{a}}\end{array}$ & Sex & Country & IGD Measures & $\begin{array}{c}\text { Psychopathology } \\
\text { Measures }\end{array}$ & $\begin{array}{c}\text { Psychopathology } \\
\text { Outcome }\end{array}$ & Association & Effect Size & $95 \%$ CI of $d$ \\
\hline & & & & & & & $\begin{array}{c}\text { Social Phobia } \\
\text { Inventory (SPIN) }\end{array}$ & Social phobia & full & $\mathrm{n} / \mathrm{a}$ & - \\
\hline $\begin{array}{l}\text { Panagiotidi, } \\
2017 \text { [42] }\end{array}$ & cross-sectional & 205 & $\begin{array}{c}\text { adults } \\
27.4 \pm 10\end{array}$ & $\mathrm{M} / \mathrm{F}$ & $\begin{array}{l}\text { United } \\
\text { Kingdom }\end{array}$ & $\begin{array}{l}\text { Problem Video-Game } \\
\text { Playing Test (PVGT) }\end{array}$ & $\begin{array}{l}\text { ADHD Self-Report Scale } \\
\text { (ASRS) }\end{array}$ & ADHD & full & $R^{2}=0.22$ & - \\
\hline \multirow[t]{4}{*}{$\begin{array}{l}\text { Gentile et al., } \\
2011[43]\end{array}$} & Longitudinal & 3034 & $\begin{array}{c}\text { children, } \\
\text { adolescents } \\
11.2 \pm 2.06\end{array}$ & $\mathrm{M} / \mathrm{F}$ & Singapore & $\begin{array}{l}\text { Pathological Technology } \\
\text { Use (PTU) }\end{array}$ & $\begin{array}{c}\text { Asian Adolescent } \\
\text { Depression Scale (AADS) }\end{array}$ & Depression & full & $R^{2}=0.49$ & - \\
\hline & & & & & & & $\begin{array}{l}\text { Child Anxiety-Related } \\
\text { Emotional } \\
\text { Disorders (SCARED) }\end{array}$ & Anxiety & full & $R^{2}=0.29$ & - \\
\hline & & & & & & & $\begin{array}{l}\text { Adult ADHD Self-Report } \\
\text { Scale (ASRS-A) }\end{array}$ & ADHD & none & - & - \\
\hline & & & & & & & $\begin{array}{c}\text { Social Phobia } \\
\text { Inventory (SPIN) }\end{array}$ & Social phobia & full & $R^{2}=0.20$ & - \\
\hline \multirow[t]{2}{*}{$\begin{array}{l}\text { Van Rooij et al., } \\
2011 \text { [44] }\end{array}$} & Longitudinal & $\begin{array}{c}\mathrm{T} 1 \\
(1572) \\
\mathrm{T} 2 \\
(1476)\end{array}$ & $\begin{array}{l}\text { children } \\
13-16\end{array}$ & $\mathrm{M} / \mathrm{F}$ & Deutschland & $\begin{array}{l}\text { Compulsive Internet Use } \\
\text { Scale (CIUS) }\end{array}$ & Depressive Mood List & $\begin{array}{l}\text { T1: Depression } \\
\text { T2: Depression }\end{array}$ & $\begin{array}{l}\text { none } \\
\text { full \# }\end{array}$ & $\mathrm{n} / \mathrm{a}$ & - \\
\hline & & & & & & & $\begin{array}{l}\text { Revised Social Anxiety } \\
\text { Scale for Children }\end{array}$ & $\begin{array}{l}\text { T1: Social anxiety } \\
\text { T2: Social anxiety }\end{array}$ & $\begin{array}{l}\text { none } \\
\text { none }\end{array}$ & - & - \\
\hline \multirow[t]{3}{*}{$\begin{array}{l}\text { Hyun et al., } \\
2015 \text { [45] }\end{array}$} & case-control & 308 & $\begin{array}{c}\text { general } \\
\text { population } \\
21.0 \pm 5.9\end{array}$ & $\mathrm{M} / \mathrm{F}$ & South Korea & $\begin{array}{l}\text { Young Internet Addiction } \\
\text { Scale (YIAS) }\end{array}$ & $\begin{array}{l}\text { Beck Depressive } \\
\text { Inventory (BDI) }\end{array}$ & Depression & full & $\mathrm{d}=1.09$ & $0.88-1.305$ \\
\hline & & & & & & & Beck Anxiety Scale (BAI) & Anxiety & full & $\mathrm{d}=0.64$ & $0.437-0.845$ \\
\hline & & & & & & & $\begin{array}{l}\text { Dupaul's ADHD } \\
\text { scale (K-ARS) }\end{array}$ & ADHD & full & $\mathrm{d}=1.05$ & $0.838-1.262$ \\
\hline $\begin{array}{l}\text { Yen et al., } \\
2016 \text { [46] }\end{array}$ & case-control & 174 & $\begin{array}{c}\text { adults } \\
23.29 \pm 2.34 \\
23.38 \pm 2.40\end{array}$ & $\mathrm{M} / \mathrm{F}$ & Taiwan & $\begin{array}{l}\text { Semi-structured interview } \\
\text { with the DSM-5 } \\
\text { IGD criteria }\end{array}$ & $\begin{array}{l}\text { ADHD DSM-IV-TR } \\
\text { criteria diagnosis for adult } \\
\text { and childhood }\end{array}$ & ADHD & full & $\begin{array}{c}\text { OR 13.51 } \\
(4.49-40.64)\end{array}$ & - \\
\hline $\begin{array}{l}\text { Brunborg et al., } \\
2014 \text { [47] }\end{array}$ & cohort & 1928 & $\begin{array}{l}\text { adolescents } \\
13-17\end{array}$ & $\mathrm{M} / \mathrm{F}$ & Norway & $\begin{array}{l}\text { Game Addiction Scale for } \\
\text { Adolescents (GASA) }\end{array}$ & $\begin{array}{l}\text { Hopkins Symptom } \\
\text { Checklist }\end{array}$ & Depression & $\begin{array}{l}\text { T1: full } \\
\text { other time: } \\
\text { none }\end{array}$ & $R^{2}=0.25$ & $\begin{array}{l}- \\
-\end{array}$ \\
\hline
\end{tabular}

a Age is presented in years as a range or mean with standard deviation (SD). M/F = both males and females analyzed together. * Low severity symptoms. $\mathrm{n} / \mathrm{a}$ Non-enough data provided to calculate the effect size or not applicable. \# When non-addicted heavy gamers and addicted heavy gamers compared. > A difference was found between IGD subjects and non IGD subjects but the psychopathology scores on both groups were not clinical. 


\subsection{Design of the Included Studies}

Nineteen of the 24 articles included were cross-sectional studies [24-42], the rest were two longitudinal studies [43,44], two case-control studies [45,46], and a cohort study [47]. The research was performed, in descending order, in South Korea (4), Australia (3), Germany (3), Norway (2), Taiwan (2), Canada (1), USA (1), Singapore (1), Spain (1), United Kingdom (1), France (1), Finland (1), Deutschland (1) Austria (1) and Sweden (1). Most of the studies were performed in European countries (12).

\subsection{Characteristics of the Used Samples}

The 24 studies had a total of 53,889 participants. All studies examined both genders. The number of participants in each study ranged from 102 to $12,938(\mathrm{M}=2155.56$; standard deviation (SD): 3176.05 ). Nine of the studies in this review [24,28,29,33,37,38,40,43,47] targeted adolescent groups, six studies [26,27,30,34,42,46] targeted adults, one [44] targeted children and eight studies [25,31,32,35,36,39,41,45] were carried out in the general population. A total of three studies were conducted in clinical populations, using people in outpatient treatment for IGD [45] or other mental health problems, namely Gambling Disorder [26] and other unspecified psychiatric problems [38].

\subsection{Methods of Assessing Internet Gaming Disorder (IGD)}

Since 2013, the DSM-5 includes a proposal of diagnostic criteria for IGD. However, only five out of 15 of the reviewed articles published after this year used these criteria [27,29,34,39,46]; three use psychometric questionnaires based on them $[30,38,40]$ to assess the problem.

These diagnostic criteria pertain to repetitive use of Internet-based games, often with other players, that leads to significant issues with functioning. Five of the following criteria must be met within one year: "(i) Preoccupation or obsession with Internet games. (ii) Withdrawal symptoms when not playing Internet games. (iii) A build-up of tolerance (i.e., more time needs to be spent playing the games). (iv) The person has tried to stop or curb playing Internet games but has failed to do so. (v) The person has had a loss of interest in other life activities, such as hobbies. (vi) A person has had continued overuse of Internet games even with awareness of how much they impact a person's life. (vii) The person has lied to others about his or her Internet game usage. (viii) The person uses Internet games to relieve anxiety or guilt (i.e., it is a way to escape). (ix) The person has lost or put at risk opportunities or relationships because of Internet games".

The questionnaires based on these criteria were the Internet Gaming Disorder Test-10 (IGDT-10) [48]; the Gaming Addiction Identification (GAIT) [49] and the Internet Gaming Disorder Scale (IGDS) [50].

The IGDT-10 includes the nine diagnostic criteria of the DSM-5. Each criterion was operationalized using a single item, except for the last criterion referring to "jeopardy or losing a significant relationship, job, or educational or career opportunity because of participation in Internet games." This criterion was operationalized with two items, given its complexity and description of more than one construct.

The GAIT is a screening instrument used to identify addictive factors related to gaming addiction in adolescents. Primarily developed based on items from the AUDIT Alcohol Consumption Questions (AUDIT-C) [51], and the criteria for gambling disorder suggested by the DSM-5, GAIT covers seven of the nine criteria in the proposed IGD criteria. These items are: preoccupation, withdrawal, tolerance, unsuccessful attempts to control the behavior, loss of interests, harm, and loss of a significant relationship or educational opportunity due to gaming. Questions regarding lying/deception to hide the gaming, and escape/mood modification, are not included.

Finally, the IGDS measures each of the nine DSM-5 definitions with three items, either through separating core aspects of a criterion into different items or by applying changes in phrasing or synonyms. Furthermore, the proposed terms "Internet gaming" or "Internet games" were replaced with "gaming" or "games." 
The remaining studies employed either measures based on the DSM-IV Gambling Disorder criteria (Pathological Technology Use (PTU), Gaming Addiction Scale (GAS)) or based on DSM-IV Addiction criteria (Gaming Addiction Scale for Adolescents (GASA), Video-game Dependency Test (VDT), Assessment of Internet and Computer Game Addiction (AICGA), Video-Game Use Questionnaire (VGUQ)), or questionnaires used to measure IA problems (Computer/Gaming-station Addiction Scale (CGAS), Generalized Problematic Internet Use Scale (GPIUS), Young Internet Addiction Scale (YIAS), Compulsive Internet Use Scale (CIUS), Problematic Internet use scale (ISS-20), Young Diagnostic Questionnaire (YDQ), Chen's Internet Addiction Scale (CIAS), and Problem Video-Game Playing Test (PVGT)).

\subsection{Methods Assessing Psychopathology}

Different psychometric assessments were used in the reviewed articles to measure psychopathology.

Depression was measured using various assessment tools, i.e., the Hopkins Symptom Checklist [52], the Asian Adolescent Depression Scale [53], the Beck Depressive Inventory [54], the Beck Depressive Inventory-II [55], the Center for Epidemiologic Studies-Depression Scale-10 [56], the Depressive Mood List [57], the Questionnaire for Depression Diagnostics [58], the Depression Self-Rating Scale [59], the Patient Health Questionnaire-9 [60] and the Depression and Somatic Symptoms Scale [61].

To assess anxiety, in each study, different measures were used, these are the State-Trait Anxiety Inventory [62], the Screen for Child Anxiety-Related Emotional Disorders [63], the Beck Anxiety Scale [64], the Spence Children's Anxiety Scale [65], and the Generalized Anxiety Disorder Scale-7 [66]. In addition, some authors used questionnaires evaluating both depression and anxiety, the Revised Children's Anxiety and Depression Scale [67], the School Health Promotion [68], the Hospital Anxiety and Depression Scale [69], the Youth Self-Report [70] and the Reynolds Adolescent Adjustment Screening Inventory [71].

To measure ADHD symptoms or hyperactivity, three authors [38,42,43] used the ADHD Self-Report Scale [72], two authors [24,37] used the Strengths and Difficulties Questionnaire [73], one author [45] used the Dupaul's ADHD scale [74], and one author [46] used the ADHD DSM-IV-TR criteria diagnosis for adult and childhood [75].

To assess social phobia and social anxiety, two studies [41,43] used the Social Phobia Inventory [76], one study [25] used the Social Phobia Scale [77], and one study [44] used the Revised Social Anxiety Scale for Children [78].

Several studies used questionnaires to assess multiple conditions: in three articles $[26,34,35]$ the Symptom Checklist 90-Revision [79] was employed to assess several conditions (somatization, obsessive-compulsive disorder, interpersonal sensitivity, depression, anxiety, hostility, phobic anxiety, paranoid ideation, and psychoticism), and one study [27] used the Brief Symptoms Inventory [80] to measure the same psychopathologies. Another study [28] evaluated depression, anxiety and obsessive-compulsive disorder through the Revised Children's Anxiety and Depression Scale [67]. Finally, one article [24] assessed emotional problems and hyperactivity using the Strengths and Difficulties Questionnaire [73].

Finally, in one study [38] the association between IGD and psychoticism was explored through the Psychotic-like Experiences Test [81].

\subsection{Effect Size of the Associations of Psychopathology with IGD}

Regarding the associations between the analyzed mental disorders and IGD, the effect sizes reported in the reviewed papers comprised different levels of association: 35 large [24-27,30,31,41-43,45-47,82], 13 moderate [26,29,31,37,45], eight small [25,33,38,40], and seven non-association [36,38,43,44,83]. In order to summarize these results, Table 2 shows the observed associations identified between IGD and psychopathology only for the main four outcomes. The largest correlations were identified 
between IGD and anxiety and depression and ADHD, whereas the weakest were observed between IGD and obsessive-compulsive disorder.

Table 2. Number of observed associations identified between IGD and psychopathology stratified by effect size for the four main outcomes.

\begin{tabular}{ccccc}
\hline Effect Size & Depression & Anxiety & ADHD/Hyper-Activity & Social Phobia/Anxiety \\
\hline Small $^{\mathrm{a}}$ & 2 & 2 & 2 & 0 \\
Moderate $^{\mathrm{b}}$ & 3 & 5 & 1 & 0 \\
Large $^{\mathrm{c}}$ & 8 & 2 & 4 & 2 \\
None & 2 & 1 & 1 & 3 \\
Total & 15 & 10 & 8 & 3 \\
\hline \multicolumn{2}{c}{$\mathrm{a}=0.2, \mathrm{R}^{2}=0.01, \mathrm{OR}=1.45 .{ }^{\mathrm{b}} \mathrm{d}=0.5, \mathrm{R}^{2}=0.06, \mathrm{OR}=2.50 .{ }^{\mathrm{c}} \mathrm{d}=0.8, \mathrm{R}^{2}=0.14, \mathrm{OR}=4.25}$.
\end{tabular}

\subsection{Psychopathology, IGD and Sample Characteristics (Age, Gender)}

Twenty-one studies were conducted in healthy populations; only three analyzed clinical populations (IGD or other mental health problems).

Regarding age, the analyzed studies included in the present review focused on three age groups as target populations: general population, adolescents and adults.

Eight articles examined groups of general population formed by children, adolescents and adults together, exploring the association between IGD and 1 depression and anxiety [31,32,39,45], depression [36,41], anxiety [25], social phobia [25,41], ADHD [45] and several psychiatric symptoms using the SCL-90-R [35]. One of these studies focused on a clinical sample of IGD patients [45]. All studies found a large effect size in the correlation between IGD in the general population and depression, except for one that found a non-correlation between both disorders. Large correlation effects with IGD in the general population were also found with ADHD and social phobia. Two studies analyzing anxiety found large effect sizes and two found moderate effect sizes. Large effect sizes were also found with the remaining SCL-90-R scales.

Six studies were focused on adults, analyzing the association between IGD and depression and anxiety [34], depression [30], ADHD [42,46] and several psychiatric symptoms [26,27]; here the SCL-90-R and the Brief Symptom Inventory (BSI) questionnaires were used. One of these studies focused on a clinical sample of pathological gamblers [26]. The authors identified correlations between IGD and depression and anxiety with large and moderate effect sizes, large effect sizes with ADHD, paranoid ideation and obsessive-compulsive symptoms, and finally, large and moderate effect sizes with the remaining SCL-90-R scales.

Adolescent participant groups were used in the remaining 10 studies. One of these studies [38] focused on adolescents with unspecified psychiatric problems. An association between depression and IGD in adolescents was found in seven articles and non-association in one; the effect sizes varied between large (2), moderate (2) and small (2) and no association (1). Anxiety correlated with IGD in adolescents in four of the five studies exploring this relationship; the sizes of the effects varied between large (1), moderate (1) and small (2). The association with ADHD was found in four out of five studies, with effect sizes: large (1), moderate (1) and small (2). Social phobia or social anxiety showed a large association and no association in two studies. Finally, non-association was found with obsessive-compulsive disorder (OCD) and psychoticism in the adolescent population.

With respect to gender, all studies reported higher video-game use among males. Seventeen studies [25-28,30,32-35,37-40,42,43,45,46] found higher rates of IGD among males. Two [24,29] reported no gender differences. The association between psychopathology and IGD was found for both sexes in all the articles (full association), except one [35] that only analyzed the relationship between males. 


\subsection{IGD and Depression}

Nineteen of the 21 studies examined some form of depression as a comorbid symptom. Thirteen studies found a full association [26,27,29-31,37,38,40,41,43,45,47,82], and two [28,36] found no association. Specifically, King et al. [28] reported association with depression in PIU groups, demonstrating significantly more severe depression and anxiety symptoms than either the non-problematic user's group or the pathological video gamers group. In contrast, the pathological video gamers group scores did not differ significantly from the non-problematic users group.

Four studies were not cross-sectional, there were two longitudinal studies $[43,44]$, one cohort study [47], and one case-control [45]. The results of these studies showed large effect size associations with depression. In the case of the longitudinal studies, Gentile et al. [43] reported elevated depressive symptoms after the pathological video-gaming problems started and these symptoms persisted and increased only if the pathological abuse persisted, while Van Rooij et al. [44], in their longitudinal study exploring two different times (years 2008 and 2009) found correlations with depressive mood only in Time 2 when comparing addicted heavy gamers with non-addicted heavy gamers. In the cohort study, the authors reported a correlation between video game addiction and depression with a large effect size only in Time 1, but they did not find any significant correlation between these two variables two years later. Among the rest of correlations detected, the effect sizes for the association with depression comprised eight large $[27,30,31,41,43,45,47,82]$, three moderate $[26,29,37]$, and two small $[38,40]$ observed effects.

\subsection{IGD and Anxiety}

Regarding the correlation between IGD and anxiety, 11 studies found a full association, one study found a partial association, and one study found no association. The studies finding full association were: a longitudinal study [43] identifying a large effect size; a case-control study [45] identifying a moderate effect size; a cross-sectional study [25], where the authors reported a large effect size in the correlation with the anxiety trait, but a small effect size with anxiety state; and eight cross-sectional studies $[26,27,29,31,32,34,38,40]$ identifying large effect sizes (1), moderate effect sizes (3), and small effect sizes (2). Just as in the case of depression, in the longitudinal study carried out by Gentile et al. [43], the anxiety symptoms appeared after pathological video-gaming problems. A partial association only in males was found in a study [35] and here there was a moderate effect size. Finally, no association with anxiety was found in one cross-sectional study [28].

\subsection{IGD and Attention Deficit Hyperactivity Disorder (ADHD)}

The relationship between IGD and ADHD and hyperactivity symptoms were analyzed in eight studies. Seven of them reported full association, with four finding large [24,42,45,46], two finding small [38,40], and one reporting moderate, effect sizes [37]. The studies comprised two case-control, five cross-sectional and one longitudinal design; the latter found no association between the two variables [43].

\subsection{IGD and Social Phobia and Social Anxiety}

Four studies included social phobia or social anxiety as a comorbid symptom in their studies. These studies comprised two longitudinal [43,44] and three cross-sectional designs $[25,41,44]$. One longitudinal and two cross-sectional studies found full association with IGD, reporting large effect sizes. Furthermore, the longitudinal study, similar to the results found regarding anxiety and depression, found that social phobia symptoms worsen after a youth becomes a pathological gamer, and improve if an individual stops this activity. In the remaining longitudinal study, no association was found between social anxiety and IGD. 


\subsection{IGD and Obsessive-Compulsive Symptoms}

Four studies examined obsessive-compulsive symptoms as a comorbid problem. Three studies $[26,27,35]$ found a full association with large effect sizes, and one [28] found no association.

\subsection{Publication Bias}

In order to detect possible publication bias, a funnel plot was conducted for depression and anxiety, as there was only a sufficient number of studies reporting results for these two pathologies (according to Grading of Recommendations, Assessment, Development and Evaluation Working Group (GRADE guides), a minimum of five to 10 studies with the same statistic reported are needed). A total of seven studies analyzing the relationship between depression and IGD, and a total of five analyzing anxiety and IGD, reported $d$ values or data to calculate them. Figure 2 depicts the distribution of the reported or calculated correlations for depression and anxiety. The $\mathrm{x}$-axis and $\mathrm{y}$-axis represent the reported $\mathrm{d}$ values and the inverse of the sample size, respectively.

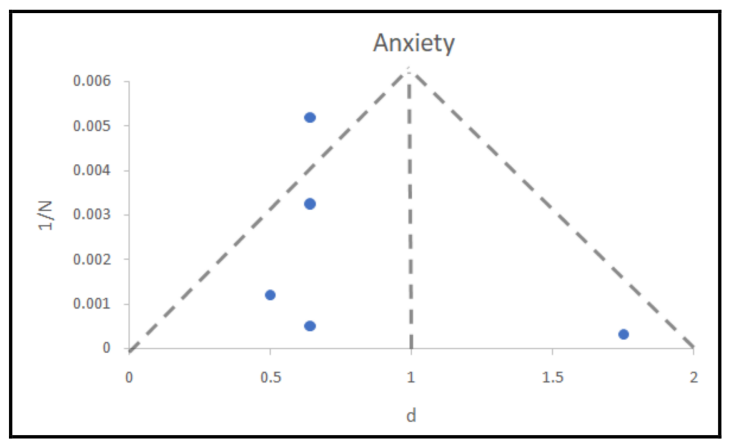

(a)

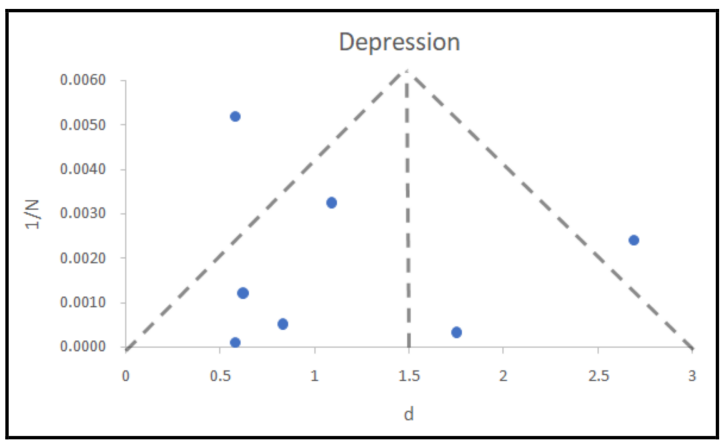

(b)

Figure 2. Funnel plots with pseudo-95\% confidence limits: (a) anxiety, (b) depression.

The location of the studies shows a bias towards the left side of the funnel plot, i.e., low values of $d$, indicating a possible publication bias. Even so, we would like to remark that the number of studies is very small to conclude with definitive results in both psychopathologies [84,85], and thus this information must be interpreted cautiously.

\section{Discussion}

The main purpose of this review was to explore the state of current literature about the relationship between IGD and comorbid psychopathologies, as this knowledge is crucial to the positioning of the disorder as a behavioral addiction. A secondary aim was to analyze the effect size of these correlations and the potential effect of publication bias. In the reviewed papers on IGD and comorbid psychological pathologies, $92 \%$ of the studies describe significant correlations with anxiety, $89 \%$ with depression, $87 \%$ with ADHD or hyperactivity symptoms, and $75 \%$ with social phobia/anxiety and obsessive-compulsive symptoms. However, the potential publication bias detected in the preliminary analysis demands caution in interpretation of the results. Notwithstanding this, it should be noted that despite the inclusion of IGD in Section III of the Diagnostic and Statistical Manual DSM-5 [7] and in the beta version of the ICD-11 (International Classification of Diseases) [8], only a marginally small number of publications were centered on IGD in the literature, and several authors continue analyzing IA or PIU as a whole, without distinguishing the different possible problematic activities that users experience with this medium.

With regard to the main purpose, IGD showed strong correlations with most of the analyzed psychopathologies, in comparison with PIU, where the strongest association was found with depression [14]. The effect sizes examined indicated that the strongest associations were found with anxiety, depression, and ADHD or hyperactivity symptoms and social phobia/anxiety. 
The fact as to whether the addictive behaviors (with or without substance use) may be a consequence or a trigger of psychopathology [15] cannot be unraveled yet. The lack of longitudinal studies analyzing the temporal linearity of these events in AI or PIU precludes clarifying whether a specific psychiatric problem helps to develop an AI or, alternatively, a person with a diagnosis of $\mathrm{AI}$ - due to negative consequences stemming from it-later developed a comorbid psychiatric disorder. A third possibility is that both problems share underlying biological, sociodemographic or psychological mechanisms that make people vulnerable to both pathologies (which manifest at the same time). In the case of this review, two longitudinal studies and one cohort study required data on whether IGD was the cause or consequence of psychopathological problems; as a result, contradictory results were obtained. On the one hand, the results of the longitudinal study performed by Gentile et al. [43] showed that the adolescents who became and stayed pathological gamers during the study period, in the last time measured, ended up with increased levels of depression, anxiety and social phobia, while those who were pathological at the start but stopped being pathological, ended up with reduced levels of depression, anxiety and social phobia. These results seem to demonstrate that gaming predicts other mental health disorders longitudinally, rather than simply being correlated with them. On the other hand, van Rooij et al. [44] found a relation between addicted heavy gamers and depression in the second year, but no correlation with social anxiety at any time. Finally, Brunborg et al. [47] only found a correlation between depression and IGD at Time 1, but not at other times.

These ambiguous results show the complex relationship between the intrinsic characteristics of online video games, the consequences of their abuse, and associated psychopathologies. The literature shows that adolescents with high scores in IGD also have negative consequences at the psychosocial level: fewer recreational activities, fewer social activities and contacts, and diminished academic performance [86,87]. These abnormalities in "real-world" social support can affect people with different personality profiles in different ways. Generally, each online video game has an associated players' community. This may lead players to find people online with similar interests and, thus, expand or replace their "real-life" social network. As these online relationships spend more and more time, "real-world" social relations will tend to deteriorate or disappear and this lack of "real-life" social support can lead some players to develop symptomatology. But in other cases, establishing this type of online relationships can help alleviate the psychological distress of some players, helping the person to establish social relationships through the Internet and build their lives around it. Some authors provide evidence that personality characteristics (e.g., extraversion, introversion) affect the choice of online or offline options for relationships [88].

Finally, age could be another key factor influencing comorbid psychopathology. In the present review, the strongest associations were found in the adult population. Results focusing on other behavioral addictions (i.e., Gambling Disorder), shows that younger adults, as opposed to older patients, only experience the symptoms of the addiction as psychological discomfort [89], without another comorbid psychopathology. One possible explanation is that older gamblers have experienced the negative consequences of the disorder for a longer period, and this has led them to develop comorbid psychopathology. It is also possible that the psychological symptoms associated with IGD require a longer time period to appear in certain subjects. Another hypothesis is that, first, children and adolescents tend to underestimate the long-term negative consequences of risky or prejudicial behaviors; and second, compared with adults, when making decisions adolescents tend to give more weight to short-term rewards compared with attendant risks [90]. Future research should analyze the differences in the perception of the negative consequences caused by IGD among adults and adolescents.

In relation to gender differences, similar to IA results all the reviewed studies reported higher video-game use among males, and most of the articles found a higher prevalence of IGD in males. Other authors have found that female respondents report less frequent play and less orientation to game genres featuring competition and three-dimensional rotation [91,92]. These characteristics in 
women players may be a protective factor against IGD. Regarding the amount of time spent playing, although contradictory results have been found regarding the relationship between this factor and IGD [31,42], some authors suggest that its control could be a protective factor in its appearance [93]. With respect to the type of video game chosen, it is likely that both the competitive factor and the immersive factor (in this case favored by a three-dimensional environment) of the online games, characteristics that women do not usually choose, may influence the development of IGD [94-96].

In order to clarify these points, future studies should focus on an analysis of the relationships between the personality of the affected people, the video-game preferences (e.g., massively multiplayer online role-playing game or MMORPG, multiplayer online battle arena or MOBA, first-person shooter gamers), the perception of the negative consequences generated by the problematic use, and the associated psychopathology.

The geographical distribution of the research in IGD seems to be more homogeneous than in IA; $50 \%$ of the included studies were developed in Europe and 50\% were conducted in the rest of the world (29\% in Asia, 30\% in Australia, and $8 \%$ in North America). The prevalence of the problem and its correlation with psychopathology has been reported in all countries; therefore, it seems that it is a global problem and independent of cultural variation.

In contrast to IA, where there is a lack of common diagnostic criteria [14], in the case of IGD there are several questionnaires available based on the proposed diagnostic criteria for the disorder in the DSM-5. Despite this inclusion, the debate about the adequacy of these criteria and the emphasis upon online gaming rather than "general" gaming addiction is still active $[97,98]$. Therefore, although there is no gold standard questionnaire for IGD, the authors have a diagnostic base in which to frame their research. In the present review, of the 15 included articles published after the appearance of the DSM-5, only eight authors used these criteria or questionnaires based on them. The rest of the published research is based on measures for IA problems or questionnaires adapted from Gambling Disorder and general addiction criteria. This variability in evaluation methods, and basing the division of the comparison groups (IGD problems vs. no IGD problems) exclusively in the results of auto-administered data, could in part explain the variability found between IGD and comorbid psychopathology.

A consensus on the evaluation method of the problem is critical; in addition, studies focused on clinical populations with a diagnosis confirmed by professionals are needed. The data based on self-reports may not be accurate and may be limited in how they diagnose people [99]; therefore, in future research it would be helpful to complement the results of self-report questionnaires with clinical interviews (at least for the positive cases).

\section{Limitations}

The results of this review should be interpreted with several limitations in mind. First (as noted), some of the studies were published before the inclusion of IGD as a diagnostic category in the DSM-5. Thus, inconsistencies in clinical definitions and evaluations should be expected. Second, restrictions applied to the language of the articles, and heterogeneity in the nomenclature surrounding IGD across the different studies, suggests a potential risk that a relevant article was missed. However, articles written in other languages (with abstracts in English) were included in the review process; furthermore, a search in the citations of the selected literature was carried out. Third, reviewing only the first 30 pages of results in Google Scholar may have produced some bias; however, this method has been shown to be commonly used [100] and seems not to influence the results of the reviews. In addition, searches in other search engines and citations of included articles may have reduced that risk.

\section{Conclusions}

The present review included 24 studies analyzing the association between IGD and psychopathology. Compared with IA (which showed strong correlations only with depression), IGD showed strong correlations with anxiety, depression, ADHD or hyperactivity symptoms, social phobia/anxiety, and obsessive-compulsive symptoms. The lack of longitudinal studies and the 
contradictory results obtained makes it difficult to detect the directionality of these associations and shows the existing complexity of the relationship between IGD and psychopathology. In addition, due to a possible publication bias, the results should be interpreted with caution.

For future research, it would be helpful to investigate the relationships between personality styles, type of video-game problem, negative consequences, and associated psychopathology. It is also necessary to reach a consensus on the diagnostic criteria of IGD and on psychometric instruments used to research the subject. Studies centered in the clinical population, with diagnostic interviews that confirm the presence of the disorder, are critically needed.

Acknowledgments: This work was funded by an AIS (Atención e InvestigaciónenSocioaddiciones) intramural research program. This research has been partially supported by the Marsden grant number E2987-3648 (Royal Society of New Zealand). This partial funder had no role in the study design, data collection, and analysis, decision to publish, or preparation of the manuscript.

Author Contributions: Vega González-Bueso and Juan José Santamaría conceived and planned the review. Vega González-Bueso and Juan José Santamaría carried out the search and revision of the literature. Juan José Santamaría and Daniel Fernández analyzed the data. Vega González-Bueso and Juan José Santamaría drafted the study. All authors (Vega González-Bueso, Juan José Santamaría, Daniel Fernández, Laura Merino, Elena Montero and Joan Ribas) revised the article critically for important intellectual content. All authors (Vega González-Bueso, Juan José Santamaría, Daniel Fernández, Laura Merino, Elena Montero and Joan Ribas) commented on and approved the final manuscript and are accountable for all aspects of the work.

Conflicts of Interest: The authors declare no conflict of interest.

\section{References}

1. King, D.L.; Haagsma, M.C.; Delfabbro, P.H.; Gradisar, M.; Griffiths, M.D. Toward a consensus definition of pathological video-gaming: A systematic review of psychometric assessment tools. Clin. Psychol. Rev. 2013, 33, 331-342. [CrossRef] [PubMed]

2. Sim, T.; Gentile, D.A.; Bricolo, F.; Serpelloni, G.; Gulamoydeen, F. A Conceptual Review of Research on the Pathological Use of Computers, Video Games, and the Internet. Int. J. Ment. Health Addict. 2012, 10, 748-769. [CrossRef]

3. King, D.L.; Delfabbro, P.H. Issues for DSM-5: Video-gaming disorder? Aust. N. Z. J. Psychiatry 2013, 47, 20-22. [CrossRef] [PubMed]

4. Starcevic, V.; Aboujaoude, E. Internet addiction: Reappraisal of an increasingly inadequate concept. CNS Spectr. 2017, 22, 7-13. [CrossRef] [PubMed]

5. Thompson, T. Demographic and motivation variables associated with Internet usage activities. Internet Res. 2001, 11, 125-137. [CrossRef]

6. Weiser, E.B. Gender Differences in Internet Use Patterns and Internet Application Preferences: A Two-Sample Comparison. CyberPsychol. Behav. 2000, 3, 167-178. [CrossRef]

7. American Psychiatric Association. Diagnostic and Statistical Manual of Mental Disorders (DSM-5), 5th ed.; American Psychiatric Association: Washington, DC, USA, 2013.

8. ICD-11 Beta Draft-Mortality and Morbidity Statistics. Available online: https://icd.who.int/dev11/l-m/en (accessed on 17 November 2017).

9. Saban, A.; Flisher, A.J. The Association between Psychopathology and Substance Use in Young People: A Review of the Literature. J. Psychoact. Drugs 2010, 42, 37-47. [CrossRef] [PubMed]

10. Petit, A.; Karila, L.; Chalmin, F.; Lejoyeux, M. Methamphetamine Addiction: A Review of the Literature. J. Addict. Res. Ther. 2012, 1, 2-7. [CrossRef]

11. Anthony, J.C. Epidemiology of drug dependence and illicit drug use. Curr. Opin. Psychiatry 1991, 4, 435-439. [CrossRef]

12. Kosten, T.R.; Ziedonis, D.M. Substance abuse and schizophrenia: Editors' introduction. Schizophr. Bull. 1997, 23, 181-186. [CrossRef] [PubMed]

13. Lehman, A.F.; Myers, C.P.; Corty, E. Assessment and classification of patients with psychiatric and substance abuse syndromes. Hosp. Community Psychiatry 1989, 40, 1019-1025. [CrossRef] [PubMed] 
14. Carli, V.; Durkee, T.; Wasserman, D.; Hadlaczky, G.; Despalins, R.; Kramarz, E.; Wasserman, C.; Sarchiapone, M.; Hoven, C.W.; Brunner, R.; et al. The association between pathological internet use and comorbid psychopathology: A systematic review. Psychopathology 2013, 46, 1-13. [CrossRef] [PubMed]

15. Dong, G.; Lu, Q.; Zhou, H.; Zhao, X. Precursor or Sequela: Pathological Disorders in People with Internet Addiction Disorder. PLoS ONE 2011, 6, e14703. [CrossRef] [PubMed]

16. Floros, G.; Siomos, K.; Stogiannidou, A.; Giouzepas, I.; Garyfallos, G. Comorbidity of psychiatric disorders with Internet addiction in a clinical sample: The effect of personality, defense style and psychopathology. Addict. Behav. 2014, 39, 1839-1845. [CrossRef] [PubMed]

17. Young, K.S. Cognitive behavior therapy with Internet addicts: Treatment outcomes and implications. Cyberpsychol. Behav. 2007, 10, 671-679. [CrossRef] [PubMed]

18. Chang, F.-C.; Chiu, C.-H.; Lee, C.-M.; Chen, P.-H.; Miao, N.-F. Predictors of the initiation and persistence of Internet addiction among adolescents in Taiwan. Addict. Behav. 2014, 39, 1434-1440. [CrossRef] [PubMed]

19. Durkee, T.; Kaess, M.; Carli, V.; Parzer, P.; Wasserman, C.; Floderus, B.; Apter, A.; Balazs, J.; Barzilay, S.; Bobes, J.; et al. Prevalence of pathological internet use among adolescents in Europe: Demographic and social factors. Addiction 2012, 107, 2210-2222. [CrossRef] [PubMed]

20. Moher, D.; Shamseer, L.; Clarke, M.; Ghersi, D.; Liberati, A.; Petticrew, M.; Shekelle, P.; Stewart, L.A. PRISMA-P Group Preferred reporting items for systematic review and meta-analysis protocols (PRISMA-P) 2015 statement. Syst. Rev. 2015, 4, 1. [CrossRef] [PubMed]

21. Available online: https://www.crd.york.ac.uk/PROSPERO/ (accessed on 17 November 2017).

22. Cohen, J. Statistical Power Analysis for the Behavioral Sciences, 2nd ed.; L. Erlbaum Associates: Hillsdale, NJ, USA, 1988; ISBN 9780805802832.

23. Chinn, S. A simple method for converting an odds ratio to effect size for use in meta-analysis. Stat. Med. 2000, 19, 3127-3131. [CrossRef]

24. Baer, S.; Bogusz, E.; Green, D.A. Stuck on screens: Patterns of computer and gaming station use in youth seen in a psychiatric clinic. J. Can. Acad. Child Adolesc. Psychiatry 2011, 20, 86-94. [PubMed]

25. Cole, S.H.; Hooley, J.M. Clinical and Personality Correlates of MMO Gaming. Soc. Sci. Comput. Rev. 2013, 31, 424-436. [CrossRef]

26. Jiménez-Murcia, S.; Fernández-Aranda, F.; Granero, R.; Chóliz, M.; La Verde, M.; Aguglia, E.; Signorelli, M.S.; Sá, G.M.; Aymamí, N.; Gómez-Peña, M.; et al. Video game addiction in gambling disorder: Clinical, psychopathological, and personality correlates. Biomed. Res. Int. 2014, 7, 105-110. [CrossRef] [PubMed]

27. Kim, N.R.; Hwang, S.S.-H.; Choi, J.-S.; Kim, D.-J.; Demetrovics, Z.; Király, O.; Nagygyörgy, K.; Griffiths, M.D.; Hyun, S.Y.; Youn, H.C.; et al. Characteristics and Psychiatric Symptoms of Internet Gaming Disorder among Adults Using Self-Reported DSM-5 Criteria. Psychiatry Investig. 2016, 13, 58. [CrossRef] [PubMed]

28. King, D.L.; Delfabbro, P.H.; Zwaans, T.; Kaptsis, D. Clinical features and axis I comorbidity of Australian adolescent pathological Internet and video game users. Aust. N. Z. J. Psychiatry 2013, 47, 1058-1067. [CrossRef] [PubMed]

29. King, D.L.; Delfabbro, P.H. The Cognitive Psychopathology of Internet Gaming Disorder in Adolescence. J. Abnorm. Child Psychol. 2016, 44, 1635-1645. [CrossRef] [PubMed]

30. Laconi, S.; Pirès, S.; Chabrol, H. Internet gaming disorder, motives, game genres and psychopathology. Comput. Hum. Behav. 2017, 75, 652-659. [CrossRef]

31. Männikkö, N.; Billieux, J.; Kääriäinen, M. Problematic digital gaming behavior and its relation to the psychological, social and physical health of Finnish adolescents and young adults. J. Behav. Addict. 2015, 4, 281-288. [CrossRef] [PubMed]

32. Mentzoni, R.A.; Brunborg, G.S.; Molde, H.; Myrseth, H.; Skouverøe, K.J.M.; Hetland, J.; Pallesen, S. Problematic Video Game Use: Estimated Prevalence and Associations with Mental and Physical Health. Cyberpsychol. Behav. Soc. Netw. 2011, 14, 591-596. [CrossRef] [PubMed]

33. Müller, K.W.; Janikian, M.; Dreier, M.; Wölfling, K.; Beutel, M.E.; Tzavara, C.; Richardson, C.; Tsitsika, A. Regular gaming behavior and internet gaming disorder in European adolescents: Results from a cross-national representative survey of prevalence, predictors, and psychopathological correlates. Eur. Child Adolesc. Psychiatry 2015, 24, 565-574. [CrossRef] [PubMed]

34. Na, E.; Lee, H.; Choi, I.; Kim, D.-J. Comorbidity of Internet gaming disorder and alcohol use disorder: A focus on clinical characteristics and gaming patterns. Am. J. Addict. 2017, 26, 326-334. [CrossRef] [PubMed] 
35. Starcevic, V.; Berle, D.; Porter, G.; Fenech, P. Problem Video Game Use and Dimensions of Psychopathology. Int. J. Ment. Health Addict. 2011, 9, 248-256. [CrossRef]

36. Stetina, B.U.; Kothgassner, O.D.; Lehenbauer, M.; Kryspin-Exner, I. Beyond the fascination of online-games: Probing addictive behavior and depression in the world of online-gaming. Comput. Hum. Behav. 2011, 27, 473-479. [CrossRef]

37. Strittmatter, E.; Kaess, M.; Parzer, P.; Fischer, G.; Carli, V.; Hoven, C.W.; Wasserman, C.; Sarchiapone, M.; Durkee, T.; Apter, A.; et al. Pathological Internet use among adolescents: Comparing gamers and non-gamers. Psychiatry Res. 2015, 228, 128-135. [CrossRef] [PubMed]

38. Vadlin, S.; Åslund, C.; Hellström, C.; Nilsson, K.W. Associations between problematic gaming and psychiatric symptoms among adolescents in two samples. Addict. Behav. 2016, 61, 8-15. [CrossRef] [PubMed]

39. Wang, H.R.; Cho, H.; Kim, D.-J. Prevalence and correlates of comorbid depression in a nonclinical online sample with DSM-5 internet gaming disorder. J. Affect. Disord. 2018, 226, 1-5. [CrossRef] [PubMed]

40. Wartberg, L.; Kriston, L.; Kramer, M.; Schwedler, A.; Lincoln, T.M.; Kammerl, R. Internet gaming disorder in early adolescence: Associations with parental and adolescent mental health. Eur. Psychiatry 2017, 43, 14-18. [CrossRef] [PubMed]

41. Wei, H.-T.; Chen, M.-H.; Huang, P.-C.; Bai, Y.-M. The association between online gaming, social phobia, and depression: An internet survey. BMC Psychiatry 2012, 12, 92. [CrossRef] [PubMed]

42. Panagiotidi, M. Problematic Video Game Play and ADHD Traits in an Adult Population. Cyberpsychol. Behav. Soc. Netw. 2017, 20, 292-295. [CrossRef] [PubMed]

43. Gentile, D.A.; Choo, H.; Liau, A.; Sim, T.; Li, D.; Fung, D.; Khoo, A. Pathological video game use among youths: A two-year longitudinal study. Pediatrics 2011, 127, e319-e329. [CrossRef] [PubMed]

44. Van Rooij, A.J.; Schoenmakers, T.M.; Vermulst, A.A.; Van Den Eijnden, R.J.J.M.; Van De Mheen, D. Online video game addiction: Identification of addicted adolescent gamers. Addiction 2011, 106, 205-212. [CrossRef] [PubMed]

45. Hyun, G.J.; Han, D.H.; Lee, Y.S.; Kang, K.D.; Yoo, S.K.; Chung, U.-S.; Renshaw, P.F. Risk factors associated with online game addiction: A hierarchical model. Comput. Hum. Behav. 2015, 48, 706-713. [CrossRef]

46. Yen, J.-Y.; Liu, T.-L.; Wang, P.-W.; Chen, C.-S.; Yen, C.-F.; Ko, C.-H. Association between Internet gaming disorder and adult attention deficit and hyperactivity disorder and their correlates: Impulsivity and hostility. Addict. Behav. 2017, 64, 308-313. [CrossRef] [PubMed]

47. Brunborg, G.S.; Mentzoni, R.A.; Frøyland, L.R. Is video gaming, or video game addiction, associated with depression, academic achievement, heavy episodic drinking, or conduct problems? J. Behav. Addict. 2014, 3, 27-32. [CrossRef] [PubMed]

48. Király, O.; Sleczka, P.; Pontes, H.M.; Urbán, R.; Griffiths, M.D.; Demetrovics, Z. Validation of the Ten-Item Internet Gaming Disorder Test (IGDT-10) and evaluation of the nine DSM-5 Internet Gaming Disorder criteria. Addict. Behav. 2017, 64, 253-260. [CrossRef] [PubMed]

49. Vadlin, S.; Åslund, C.; Nilsson, K.W. Development and content validity of a screening instrument for gamingaddiction in adolescents: The Gaming Addiction Identification Test (GAIT). Scand. J. Psychol. 2015, 56, 458-466. [CrossRef] [PubMed]

50. Lemmens, J.S.; Valkenburg, P.M.; Gentile, D.A. The Internet Gaming Disorder Scale. Psychol. Assess. 2015, 27, 567-582. [CrossRef] [PubMed]

51. Bush, K.; Kivlahan, D.R.; McDonell, M.B.; Fihn, S.D.; Bradley, K.A. The AUDIT alcohol consumption questions (AUDIT-C): An effective brief screening test for problem drinking. Ambulatory Care Quality Improvement Project (ACQUIP). Alcohol Use Disorders Identification Test. Arch. Intern. Med. 1998, 158, 1789-1795. [CrossRef] [PubMed]

52. Derogatis, L.R.; Lipman, R.S.; Rickels, K.; Uhlenhuth, E.H.; Covi, L. The Hopkins Symptom Checklist (HSCL): A self-report symptom inventory. Behav. Sci. 1974, 19,1-15. [CrossRef] [PubMed]

53. Woo, B.S.C.; Chang, W.C.; Fung, D.S.S.; Koh, J.B.K.; Leong, J.S.F.; Kee, C.H.Y.; Seah, C.K.F. Development and validation of a depression scale for Asian adolescents. J. Adolesc. 2004, 27, 677-689. [CrossRef] [PubMed]

54. Beck, A.T.; Ward, C.H.; Mendelson, M.; Mock, J.; Erbaugh, J. An inventory for measuring depression. Arch. Gen. Psychiatry 1961, 4, 561-571. [CrossRef] [PubMed]

55. Beck, A.T.; Steer, R.A.; Ball, R.; Ranieri, W.F. Comparison of Beck Depression Inventories-IA and-II in Psychiatric Outpatients. J. Pers. Assess. 1996, 67, 588-597. [CrossRef] [PubMed] 
56. Andresen, E.M.; Malmgren, J.A.; Carter, W.B.; Patrick, D.L. Screening for depression in well older adults: Evaluation of a short form of the CES-D (Center for Epidemiologic Studies Depression Scale). Am. J. Prev. Med. 1994, 10, 77-84. [CrossRef]

57. Kandel, D.B.; Davies, M. Epidemiology of depressive mood in adolescents: An empirical study. Arch. Gen. Psychiatry 1982, 39, 1205-1212. [CrossRef] [PubMed]

58. Kühner, C. Fragebogen zur Depressionsdiagnostik nach DSM-IV (FDD-DSMIV); Hogrefe: Göttingen, Germany, 1997.

59. Svanborg, P.; Ekselius, L. Self-assessment of DSM-IV criteria for major depression in psychiatric out- and inpatients. Nord. J. Psychiatry 2003, 57, 291-296. [CrossRef] [PubMed]

60. Spitzer, R.L.; Kroenke, K.; Williams, J.B. Validation and utility of a self-report version of PRIME-MD: The PHQ primary care study. Primary Care Evaluation of Mental Disorders. Patient Health Questionnaire. JAMA 1999, 282, 1737-1744. [CrossRef] [PubMed]

61. Hung, C.-I.; Wang, S.-J.; Liu, C.-Y. Validation of the Depression and Somatic Symptoms Scale by comparison with the Short Form 36 scale among psychiatric outpatients with major depressive disorder. Depress. Anxiety 2009, 26, 583-591. [CrossRef] [PubMed]

62. Spielberger, C.; Gorsuch, R.L.; Lushene, R.E. Manual for the State/Trait Anxiety Inventory; Consulting Psychologists Press: Palo Alto, CA, USA, 1970.

63. Birmaher, B.; Khetarpal, S.; Brent, D.; Cully, M.; Balach, L.; Kaufman, J.; Neer, S.M. The Screen for Child Anxiety Related Emotional Disorders (SCARED): Scale construction and psychometric characteristics. J. Am. Acad. Child Adolesc. Psychiatry 1997, 36, 545-553. [CrossRef] [PubMed]

64. Beck, A.T.; Epstein, N.; Brown, G.; Steer, R.A. An inventory for measuring clinical anxiety: Psychometric properties. J. Consult. Clin. Psychol. 1988, 56, 893-897. [CrossRef] [PubMed]

65. Spence, S.H. A measure of anxiety symptoms among children. Behav. Res. Ther. 1998, 36, 545-566. [CrossRef]

66. Spitzer, R.L.; Kroenke, K.; Williams, J.B.W.; Löwe, B. A Brief Measure for Assessing Generalized Anxiety Disorder. Arch. Intern. Med. 2006, 166, 1092. [CrossRef] [PubMed]

67. Chorpita, B.F.; Yim, L.; Moffitt, C.; Umemoto, L.A.; Francis, S.E. Assessment of symptoms of DSM-IV anxiety and depression in children: A revised child anxiety and depression scale. Behav. Res. Ther. 2000, 38, 835-855. [CrossRef]

68. Kunttu, K.; Pesonen, T. Student Health Survey 2012: A National Survey among Finnish University Students; Finnish Student Health Service; Ylioppilaiden Terveydenhoitosäätiön Tutkimuksia 47: Helsinki, Finland, 2013.

69. Zigmond, A.S.; Snaith, R.P. The hospital anxiety and depression scale. Acta Psychiatr. Scand. 1983, 67, 361-370. [CrossRef] [PubMed]

70. Achenbach, T. Manual for the Youth Self-Report and 1991 Profile; Department of Psychiatry, University of Vermont: Burlington, VT, USA, 1999.

71. Reynolds, W. Reynolds Adolescent Adjustment Screening InventoryTM (RAASITM): Professional Manual; Psychological Assessment Resources: Lutz, FL, USA, 2001.

72. Kessler, R.C.; Adler, L.; Ames, M.; Demler, O.; Faraone, S.; Hiripi, E.; Howes, M.J.; Jin, R.; Secnik, K.; Spencer, T; et al. The World Health Organization Adult ADHD Self-Report Scale (ASRS): A short screening scale for use in the general population. Psychol. Med. 2005, 35, 245-256. [CrossRef] [PubMed]

73. Goodman, R. The Strengths and Difficulties Questionnaire: A research note. J. Child Psychol. Psychiatry 1997, 38, 581-586. [CrossRef] [PubMed]

74. DuPaul, G.J. Parent and Teacher Ratings of ADHD Symptoms: Psychometric Properties in a CommunityBased Sample. J. Clin. Child Psychol. 1991, 20, 245-253. [CrossRef]

75. American Psychiatric Association. Diagnostic and Statistical Manual of Mental Disorders, 4th ed.; American Psychiatric Association Text Revision: Arlington, TA, USA, 2000.

76. Connor, K.M.; Davidson, J.R.; Churchill, L.E.; Sherwood, A.; Foa, E.; Weisler, R.H. Psychometric properties of the Social Phobia Inventory (SPIN). New self-rating scale. Br. J. Psychiatry 2000, 176, 379-386. [CrossRef] [PubMed]

77. Mattick, R.P.; Clarke, J.C. Development and validation of measures of social phobia scrutiny fear and social interaction anxiety. Behav. Res. Ther. 1998, 36, 455-470. [CrossRef]

78. La Greca, A.M.; Stone, W.L. Social Anxiety Scale for Children-Revised: Factor Structure and Concurrent Validity. J. Clin. Child Psychol. 1993, 22, 17-27. [CrossRef] 
79. Derogatis, L.R. SCL-90-R. Administration, Scoring and Procedures Manual; Clinical Psychometric Research Inc.: Baltimore, MD, USA, 1990.

80. Derogatis, L.R.; Melisaratos, N. The Brief Symptom Inventory: An introductory report. Psychol. Med. 1983, 13, 595-605. [CrossRef] [PubMed]

81. Laurens, K.; Hodgins, S.; MaughanN, B.; Murray, R.; Rutter, M.; Taylor, E. Community screening for psychotic-like experiences and other putative antecedents of schizophrenia in children aged 9-12 years. Schizophr. Res. 2007, 90, 130-146. [CrossRef] [PubMed]

82. STARCEVIC, V. Problematic Internet use: A distinct disorder, a manifestation of an underlying psychopathology, or a troublesome behaviour? World Psychiatry 2010, 9, 92-93. [CrossRef] [PubMed]

83. King, D.L.; Delfabbro, P.H.; Griffiths, M.D. Trajectories of Problem Video Gaming Among Adult Regular Gamers: An 18-Month Longitudinal Study. Cyberpsychol. Behav. Soc. Netw. 2013, 16, 72-76. [CrossRef] [PubMed]

84. Monroe, J. Meta-Analysis for Observational Studies: Statistical Methods for Heterogeneity, Publication Bias and Combining Studies: Statistics; University of California: Los Angeles, CA, USA, 2007.

85. Sutton, A.J. Methods for Meta-Analysis in Medical Research; J. Wiley: Chichester, UK, 2000; ISBN 9780471490661.

86. Beutel, M.E.; Hoch, C.; Wölfling, K.; Müller, K.W. Clinical characteristics of computer game and internet addiction in persons seeking treatment in an outpatient clinic for computer game addiction. Z. Psychosom. Med. Psychother. 2011, 57, 77-90. [CrossRef] [PubMed]

87. Batthyány, D.; Müller, K.W.; Benker, F.; Wölfling, K. Computer game playing: Clinical characteristics of dependence and abuse among adolescents. Wien. Klin. Wochenschr. 2009, 121, 502-509. [CrossRef] [PubMed]

88. Goby, V.P. Personality and Online/Offline Choices: MBTI Profiles and Favored Communication Modes in a Singapore Study. Cyberpsychol. Behav. 2006, 9, 5-13. [CrossRef] [PubMed]

89. González-Ibáñez, A.; Mora, M.; Gutiérrez-Maldonado, J.; Ariza, A.; Lourido-Ferreira, M.R. Pathological gambling and age: Differences in personality, psychopathology, and response to treatment variables. Addict. Behav. 2005, 30, 383-388. [CrossRef] [PubMed]

90. Halpern-Felsher, B.L.; Cauffman, E. Costs and benefits of a decision: Decision-making competence in adolescents and adults. J. Appl. Dev. Psychol. 2001, 22, 257-273. [CrossRef]

91. Lucas, K.; Sherry, J.L. Sex Differences in Video Game Play. Commun. Res. 2004, 31, 499-523. [CrossRef]

92. Greenberg, B.S.; Sherry, J.; Lachlan, K.; Lucas, K.; Holmstrom, A. Orientations to Video Games Among Gender and Age Groups. Simul. Gaming 2010, 41, 238-259. [CrossRef]

93. Young, K. Understanding Online Gaming Addiction and Treatment Issues for Adolescents. Am. J. Fam. Ther. 2009, 37, 355-372. [CrossRef]

94. Floros, G.; Siomos, K. Patterns of Choices on Video Game Genres and Internet Addiction. Cyberpsychol. Behav. Soc. Netw. 2012, 15, 417-424. [CrossRef] [PubMed]

95. Elliott, L.; Golub, A.; Ream, G.; Dunlap, E. Video Game Genre as a Predictor of Problem Use. Cyberpsychol. Behav. Soc. Netw. 2012, 15, 155-161. [CrossRef] [PubMed]

96. King, D.; Delfabbro, P.; Griffiths, M. Video Game Structural Characteristics: A New Psychological Taxonomy. Int. J. Ment. Health Addict. 2010, 8, 90-106. [CrossRef]

97. Petry, N.M.; Rehbein, F.; Gentile, D.A.; Lemmens, J.S.; Rumpf, H.-J.; Mößle, T.; Bischof, G.; Tao, R.; Fung, D.S.S.; Borges, G.; et al. An international consensus for assessing internet gaming disorder using the new DSM-5 approach. Addiction 2014, 109, 1399-1406. [CrossRef] [PubMed]

98. Kuss, D.J.; Griffiths, M.D.; Pontes, H.M. Chaos and confusion in DSM-5 diagnosis of Internet Gaming Disorder: Issues, concerns, and recommendations for clarity in the field. J. Behav. Addict. 2017, 6, 103-109. [CrossRef] [PubMed]

99. Bhandari, A.; Wagner, T. Self-Reported Utilization of Health Care Services: Improving Measurement and Accuracy. Med. Care Res. Rev. 2006, 63, 217-235. [CrossRef] [PubMed]

100. Kaptsis, D.; King, D.; Delfabbro, P.; Gradisar, M. Withdrawal symptoms in internet gaming disorder: A systematic review. Clin. Psychol. Rev. 2016, 43, 58-66. [CrossRef] [PubMed]

(C) 2018 by the authors. Licensee MDPI, Basel, Switzerland. This article is an open access article distributed under the terms and conditions of the Creative Commons Attribution (CC BY) license (http:/ / creativecommons.org/licenses/by/4.0/). 